\section{Meta-Analysis of Prevalence of Xerostomia in Diabetes Mellitus}

\author{
Luiza Silveira Lessa1,2,3 , Patrícia Duarte Simões Pires², \\ Renan Antônio Ceretta², Indianara Reynaud Toreti Becker', \\ Luciane Bisognin Ceretta1,2,3, Lisiane Tuon 1,3, \\ Priscyla Waleska Simões ${ }^{1,2,3}$, Fernanda Guglielmi Faustini Sônego ${ }^{1,2}$
}

\section{Abstract}

Background: As with other complications of diabetes mellitus, the occurrence of dry mouth can lead to a poor quality of life. Therefore, this study aimed to identify the prevalence of xerostomia in patients with diabetes mellitus through a systematic review and meta-analysis.

Method: Systematic review and meta-analysis.

Results: After the screening process, 23 studies were included in the meta-analysis. Overall, the incidence of dry mouth was investigated in 1979 people with diabetes (cases) and 1225 controls. The global prevalence of diabetes in xerostomia was $42.22 \%$ (95\% Cl: $33.97 \%-$ $50.92 \%)$. In the analysis by specific subtype, the overall prevalence was 37.42\% (95\% Cl: 22.33\%-55.44\%) among individuals with Type 1 diabetes and $46.09 \%$ (95\% Cl: 23.99\%-69.85\%) among those with type 2 diabetes. The prevalence of xerostomia found in Asia (49.01\%; 95\% Cl: 32.08\%-66.16\%) was higher than that found in Europe (40.04\%; 95\% Cl: 29.58\%-51.50\%) and America (38.39\%; 95\% Cl: $23.63 \%-55.65 \%)$. Analysis of the case-control studies showed a statistically significant association between xerostomia and diabetes mellitus (OR=3.15; 95\% Cl: 2.11-4.70; $\mathrm{p}<0.001)$.

Conclusion: Through the data collected, we can infer that the prevalence of xerostomia in individuals affected by diabetes mellitus types 1 and 2 was high and independent of geographic location.
1 Multidisciplinary Residency Program in Primary Care/Family Health. Universidade do Extremo Sul Catarinense (UNESC), Criciúma, SC, Brazil.

2 Dentistry Course. Universidade do Extremo Sul Catarinense (UNESC) Criciúma, SC, Brazil.

3 Graduate Program in Public Health (PPGSCol). Universidade do Extremo Sul Catarinense (UNESC) Criciúma, SC, Brazil.

\section{Contact information:}

Fernanda Guglielmi Faustini Sônego. Multidisciplinary Residency Program in Primary Care/Family Health.

\section{Priscyla Waleska Simões.}

Multidisciplinary Residency Program in Primary Care/Family Health. Graduate Program in Public Health (PPGSCol).

Address: Universidade do Extremo Sul Catarinense (UNESC), Av. Universitária, 1105 -Bairro Universitário, CEP: 88806-000 -Criciúma-SC. Tel: 5548 3431-2500.

¡fgfsonego@unesc.net झ pri@unesc.net

\title{
Keywords
}

Diabetes Mellitus; Xerostomia; Systematic Review; Meta-Analysis. 


\section{Introduction}

Recent studies show that non-communicable chronic diseases (NCCD) are a major threat to the health of the population, accounting for $60.3 \%$ of all deaths in the world in 2008 [1]. In this context, diabetes mellitus is one of the four NCCD groups that cause the most deaths, along with cardiovascular diseases, cancer and respiratory chronic diseases [1].

Worldwide, it is estimated that the overall number of people between 20 and 79 years old with diabetes was 382 million in 2013 and will reach 592 million by 2035. In Brazil, which is fourth among the 10 countries with the highest prevalence of diabetes, the number of people with diabetes is projected to increase from 11.9 to 19.2 million in the same period [2]. These projections corroborate the data found in a national survey conducted in 2008, which noted that diabetes mellitus has been the chronic disease with the highest growth (37\%) since 2003 [3].

According to the World Health Organization (WHO), diabetes mellitus consists of a disturbance in the production and/or action of insulin [4]. This hormone deficiency leads to hyperglycemia, often associated with dysfunction, damage and failure of various organs $[5,6]$.

Xerostomia, defined as a dry mouth sensation with or without salivary gland hypofunction, is an oral condition with variable etiology. Its prevalence increases with age, affecting approximately $30 \%$ of the population over 65 years old [7]. Considered one of the main oral disorders related to saliva, its symptoms include halitosis, pain, burning mouth, taste alterations, and difficulties in swallowing and speaking [8]. Additionally, patients with xerostomia may be at increased risk for dental caries, as they often resort to candies and acidic drinks to relieve their symptoms [8].

As with other complications of diabetes mellitus, the occurrence of dry mouth can lead to a poor quality of life. Therefore, this study aimed to identify the prevalence of xerostomia in patients with diabetes mellitus through a systematic review and meta-analysis.

\section{Methods}

\section{Search strategy}

A comprehensive search of MEDLINE (via PubMed), LILACS, SCOPUS, Central Register of Controlled Studies of Cochrane, IBECS, BIOSIS and Web of Science was performed for relevant studies published from July 1977 to December 2014 using MeSH descriptors and synonyms, including "xerostomia", "dry mouth", "mouth dryness", "oral dryness" and "buccal dryness" associated with "diabetes mellitus". The terms were combined using the Boolean operators "AND", "OR" and "NOT".

In addition, reference lists were checked in all of the recovered primary studies, and a search of grey literature was conducted. The overall search was limited to studies in humans, but there was no language restriction.

The primary analysis of recovered abstracts and titles was performed independently by four researchers (LSL, PP, PWS and FGFS). Publications considered potentially relevant that met the necessary criteria were selected for full reading, which was carried out by five researchers (LSL, PP, PWS, RC and IRTB). In both cases, disagreements regarding the inclusion or exclusion of each study were resolved by consensus involving other researchers (LT and LC).

The agreement between reviewers was measured through the Kappa statistical test $(k)$ using a classification proposed by Higgins and Green [11], in which values $\geq 0.40$ and $<0.59$ were considered fair agreement, values $\geq 0.60$ and $<0.74$ were considered good agreement, and values $\geq 0.75$ were considered excellent agreement.

\section{Study selection}

Cross-sectional and case-control studies assessing the prevalence of xerostomia in individuals affected 
by diabetes mellitus were included. As to the diagnostic criteria, diabetes was diagnosed in only those individuals with fasting plasma glucose $\geq 126 \mathrm{mg} /$ $\mathrm{dL}$, random plasma glucose $>200 \mathrm{mg} / \mathrm{dL}$ associated with classic symptoms, plasma glucose > 200 mg/ $\mathrm{dL}$ two hours after ingesting $75 \mathrm{~g}$ of oral glucose (Oral Glucose Tolerance Test - OGTT) or a glycated hemoglobin level $(\mathrm{HbA} 1 \mathrm{c}) \geq 6.5 \%$ [9], and who were under medical care with a diagnosis of diabetes made prior to the study in which they were included.

Regarding xerostomia, because it is a subjective condition, the diagnosis was considered appropriate in cases where the presence of symptoms was reported by the subjects themselves, after being questioned by the researchers [8].

The prevalence analysis by specific subtype was performed in only individuals with types 1 and 2 diabetes mellitus as the other forms of the disease, gestational diabetes and other specific subtypes, stem from pre-existing conditions, capable of affecting the results. Additionally, these other forms are less common and therefore have been poorly explored in the literature.

To minimize possible risk factors for xerostomia and evaluate its prevalence solely in patients with diabetes mellitus, other illnesses associated with xerostomia, such as Sjögren's Syndrome, were excluded from the meta-analysis.

\section{Data synthesis and statistical analysis}

We collected data regarding year of publication, country, age and gender of the subjects, as well as the number of individuals with xerostomia and diabetes (with specific subtype), when specified by the authors.

For the meta-analysis, prevalence rates of xerostomia in people with diabetes were pooled using the random effects model [10]. Heterogeneity was calculated via Cochrane's Q and $\tau^{2}$ tests, and inconsistency was presented by $\left.\right|^{2}$, which describes the percentage of variability that is due to heterogeneity rather than chance [10].
Additionally, case-control studies were summarized according to their odds ratios (OR) and pooled using the random effects model [11]. In studies in which only one cell of the $2 \times 2$ contingency table showed a value of 0 (zero), the value 0.5 was added to enable the OR calculation; however, those in which the value 0 (zero) occurred in two cells or more were removed from the analysis [11].

Given the heterogeneity, a subgroup analysis by continent (Europe, Asia and America) and specific subtype of diabetes (Type 1 and Type 2 Diabetes Mellitus) was carried out.

The possibility of publication bias (the tendency of studies with negative results to be less likely to be published) was assessed by Egger's test and graphical analysis of funnel plots. In funnel plots, each dot represents a study, its effect size or prevalence, and the standard error, for example [11, 12]. Among the cases, a logit transformation was performed on each study included for publication bias assessment.

The meta-analysis was conducted using $R$ 3.1.1 software (Comprehensive R Archive Network, http:// cran.r-project.org/), and the graphical representation was conducted using forest plots.

\section{Results}

Our initial search of the selected databases retrieved 187 potentially relevant publications for the analysis of titles and abstracts. Of this total, 53 articles were selected for full reading, whereas the remaining 134 were excluded due to study design, association with other diseases or lack of data related to the occurrence of xerostomia in people with diabetes. After reading 53 full papers, 30 were excluded due to insufficient data, data duplication, or associated diseases, qualifying 23 papers for the meta-analysis. This process is summarized in Figure 1. The agreement between the eligibility of studies was considered excellent ( $k=$ 0.91) [11]. 
Figure 1: Flowchart of study selection for meta-analysis.

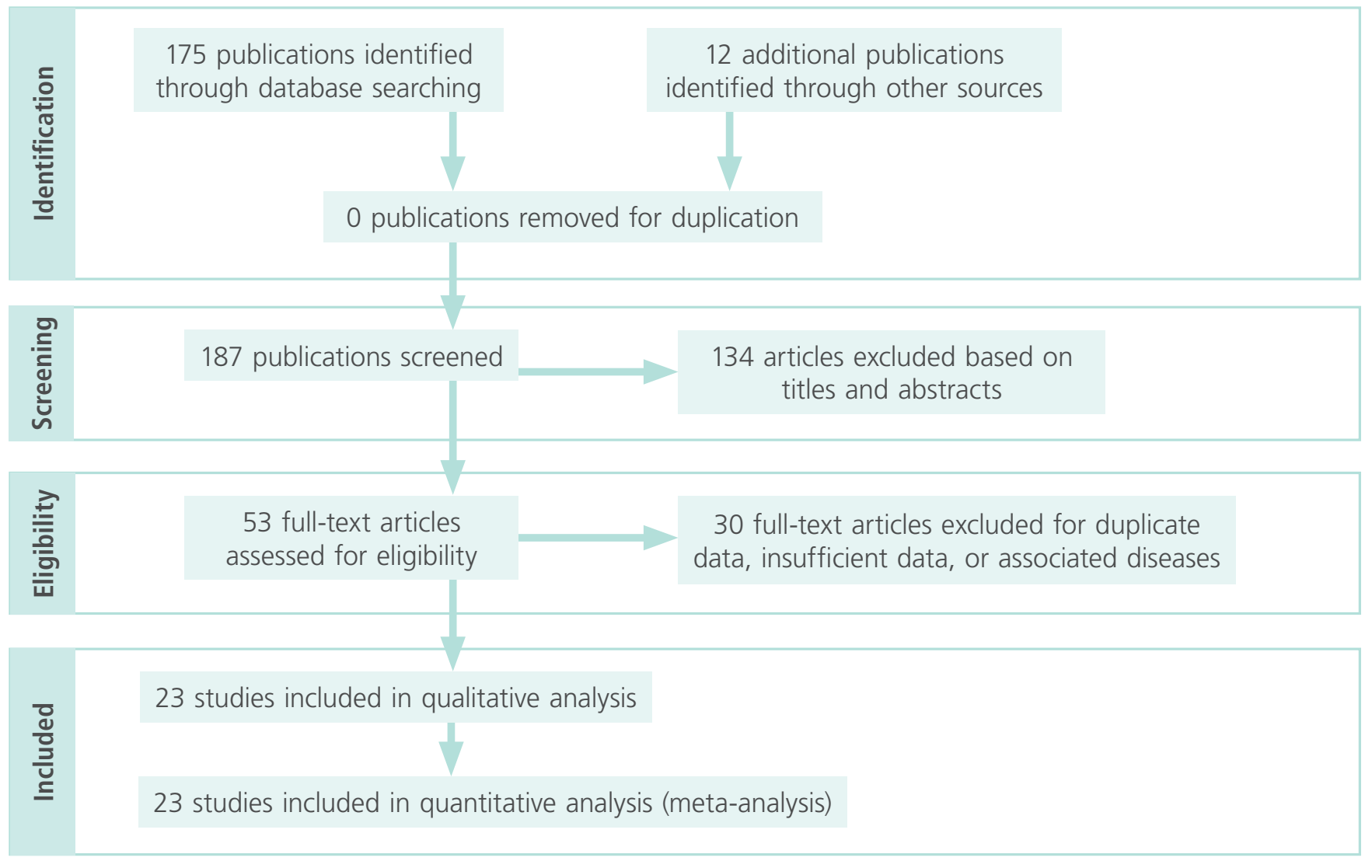

Among the selected studies, published between 1989 and 2014, 8 were conducted in Europe [14, $15,18,19,25,28,29,32], 5$ were conducted in Asia $[13,16,23,24,30]$ and 100 were conducted in America [17, 20-22, 26, 27, 31, 33-35]. Overall, the occurrence of dry mouth was investigated in 1979 in people with diabetes (cases) and 1667 controls, whereas in 15 articles, the authors subdivided the outcome into types 1 and 2 diabetes mellitus (Table 1). The prevalence ranged from 3.33\% (95\% Cl: $00.08 \%-17.22 \%$ ) to $85.42 \%$ (95\% Cl: $72.24 \%-$ $93.93 \%)$, reaching a global average of $42.22 \%$

Table 1. Papers included in the meta-analysis.

\begin{tabular}{|c|c|c|c|c|c|c|}
\hline Author & Country & Continent & $\begin{array}{c}\text { Patients } \\
\text { with } \\
\text { xerostomia/ } \\
\text { Cases }\end{array}$ & $\begin{array}{c}\text { Prevalence (Cases) } \\
\%(95 \% \mathrm{CI})\end{array}$ & $\begin{array}{c}\text { Patients } \\
\text { with } \\
\text { xerostomia/ } \\
\text { Controls }\end{array}$ & OR $(95 \% \mathrm{CI})$ \\
\hline Al-Maweri 2013 [13] & Malaysia & Asia & $119 / 391$ & $30.43(25.91-35.26)$ & & \\
\hline $\begin{array}{l}\text { Arrieta-Blanco } 2003 \\
\text { [14] }\end{array}$ & Spain & Europe & $20 / 70$ & $28.57(18.40-40.62)$ & $8 / 74$ & $3.30(1.34-8.10)$ \\
\hline Belazi 2005 [15] & Greece & Europe & $24 / 46$ & $52.17(36.95-67.11)$ & $8 / 50$ & $5.72(2.21-14.83)$ \\
\hline Ben-Aryeh 1993 [16] & Israel & Asia & 9/39 & 23.08 (11.13-39.33) & $3 / 20$ & $1.70(0.40-7.14)$ \\
\hline Busato 2012 [17] & Brazil & America & $27 / 51$ & $52.94(38.46-67.07)$ & & \\
\hline
\end{tabular}




\begin{tabular}{|c|c|c|c|c|c|c|}
\hline Author & Country & Continent & $\begin{array}{l}\text { Patients } \\
\text { with } \\
\text { xerostomia/ } \\
\text { Cases }\end{array}$ & $\begin{array}{c}\text { Prevalence (Cases) } \\
\%(95 \% \mathrm{Cl})\end{array}$ & $\begin{array}{l}\text { Patients } \\
\text { with } \\
\text { xerostomia/ } \\
\text { Controls }\end{array}$ & OR $(95 \% \mathrm{Cl})$ \\
\hline Carda 2006 [18] & Spain & Europe & 13/17 & $76.47(50.10-93.19)$ & $3 / 16$ & $14.08(2.61-75.77)$ \\
\hline Collin 2000 [19] & Finland & Europe & $25 / 45$ & $55.56(40.00-70.36)$ & $28 / 77$ & $2.18(1.03-4.62)$ \\
\hline Costa 2004 [20] & Brazil & America & $10 / 26$ & $38.46(20.23-59.43)$ & & \\
\hline Gilbert 1993 [21] & USA & America & $41 / 82$ & $50.00(38,75-61,25)$ & $162 / 505$ & $2.11(1.32-3.39)$ \\
\hline $\begin{array}{l}\text { Gonzaléz-Guevara } \\
2008 \text { [22] }\end{array}$ & Mexico & America & $119 / 162$ & $73.46(65.96-80.08)$ & & \\
\hline Javed 2009 [23] & Pakistan & Asia & $41 / 48$ & $85.42(72.24-93.93)$ & $0 / 40$ & $448.20(24.77-8107.12)$ \\
\hline $\begin{array}{l}\text { Khovidhunkit } 2009 \\
\text { [24] }\end{array}$ & Thailand & Asia & $95 / 154$ & $61.69(53.52-69.40)$ & $18 / 50$ & $2.86(1.47-5.55)$ \\
\hline Malicka 2014 [25] & Poland & Europe & 23/93 & $24.73(16.37-34.76)$ & $10 / 63$ & $1.74(0.76-3.96)$ \\
\hline Merchant 2012 [26] & USA & America & 23/155 & $14.84(09.64-21.43)$ & & \\
\hline Moreira 2009 [27] & Brazil & America & $19 / 30$ & $63.33(43.86-80.07)$ & $0 / 30$ & $103.43(5.76-1857.21)$ \\
\hline Närhi 1996 [28] & Finland & Europe & $5 / 12$ & $41.67(15.17-72.33)$ & $9 / 32$ & $1.82(0.45-7.27)$ \\
\hline Sandberg 2001 [29] & Sweden & Europe & $13 / 36$ & $36.11(20.82-53.78)$ & 29/102 & $1.42(0.63-3.18)$ \\
\hline Shrestha 2013 [30] & Nepal & Asia & $88 / 200$ & $44.00(37.01-51.17)$ & & \\
\hline Sreebny 1992 [31] & USA & America & $17 / 40$ & $42.50(27.04-59.11)$ & & \\
\hline $\begin{array}{l}\text { Thorstensson } 1989 \\
\text { [32] }\end{array}$ & Sweden & Europe & $48 / 180$ & $26.67(20.36-33.76)$ & $5 / 86$ & $5.89(2.25-15.41)$ \\
\hline $\begin{array}{l}\text { Vasconcelos } 2008 \\
\text { [33] }\end{array}$ & Brazil & America & $1 / 30$ & $03.33(00.08-17.22)$ & & \\
\hline $\begin{array}{l}\text { Vasconcelos } 2010 \\
\text { [34] }\end{array}$ & Brazil & America & $5 / 40$ & $12.50(04.19-26.80)$ & $2 / 40$ & $2.71(0.49-14.90)$ \\
\hline Zielinski 2002 [35] & USA & America & $16 / 32$ & $50.00(31.89-68.11)$ & $12 / 40$ & $2.33(0.88-6.14)$ \\
\hline Total & & & $801 / 1979$ & $42.22(33.97-50.92)$ & 297/1225 & $3.15(2.11-4.70)$ \\
\hline
\end{tabular}

(95\% Cl: 33.97\%-50.92\%). The heterogeneity found within the studies was high $\left(I^{2}=92.1 \% ; \tau^{2}=\right.$ 0.6153; $p<0.001)$.

In the analysis by specific subtype, the prevalence was 37.42\% (95\% Cl: 22.33\%-55.44\%) among individuals with Type 1 diabetes and 46.09\% (95\% Cl: 23 99\%-69.85\%) among those with type 2 diabetes, as shown in Figure 2.

Regarding the analysis by continent, the prevalence of xerostomia found in Asia (49.01\%; 95\% Cl: $32.08 \%-66.16 \%)$ was higher than that in Euro- pe (40.04\%, 95 \%: 29.58\%-51.50\%) and America (38.39\%; 95\% Cl: 23.63\%-55.65\%) (Figure 3).

The assessment of the research subjects' profiles revealed a majority of women ( $n=1337$ vs. $n=975$ for men) both in the groups with diabetes and the controls. The mean age of the participants in the 19 studies ranged from $10.3( \pm 4.2)$ to $79.8( \pm 4.3)$ in the in people with diabetes and from $11.23( \pm 2.7)$ to $78.5( \pm 3.6)$ in the controls.

In the analysis of case-control studies [14-16, 18, $19,21,23-25,27-29,32,34,35]$, the characte- 
Figure 2: Prevalence of xerostomia in patients with diabetes mellitus types 1 (a) and 2 (b).

a

Study

Busato 2012

Costa 2004

Javed 2009

Malicka 2014

Merchant 2012

Moreira 2009

Random effects model

Heterogeneity: 1 -squared $=92.6 \%$, tau-square

b

Study

Al-Maweri 2013

Belazi 2005

Carda 2006

Collin 2000

González-Guevara 2008

Khovidhunkit 2009

Malicka 2014

Merchant 2012

Sandberg 2001

Shrestha 2013

Vasconcelos 2010

Random effects model

Heterogeneity: l-squared $=95.7 \%$, tau-squared

\section{Events Total}

Events Total
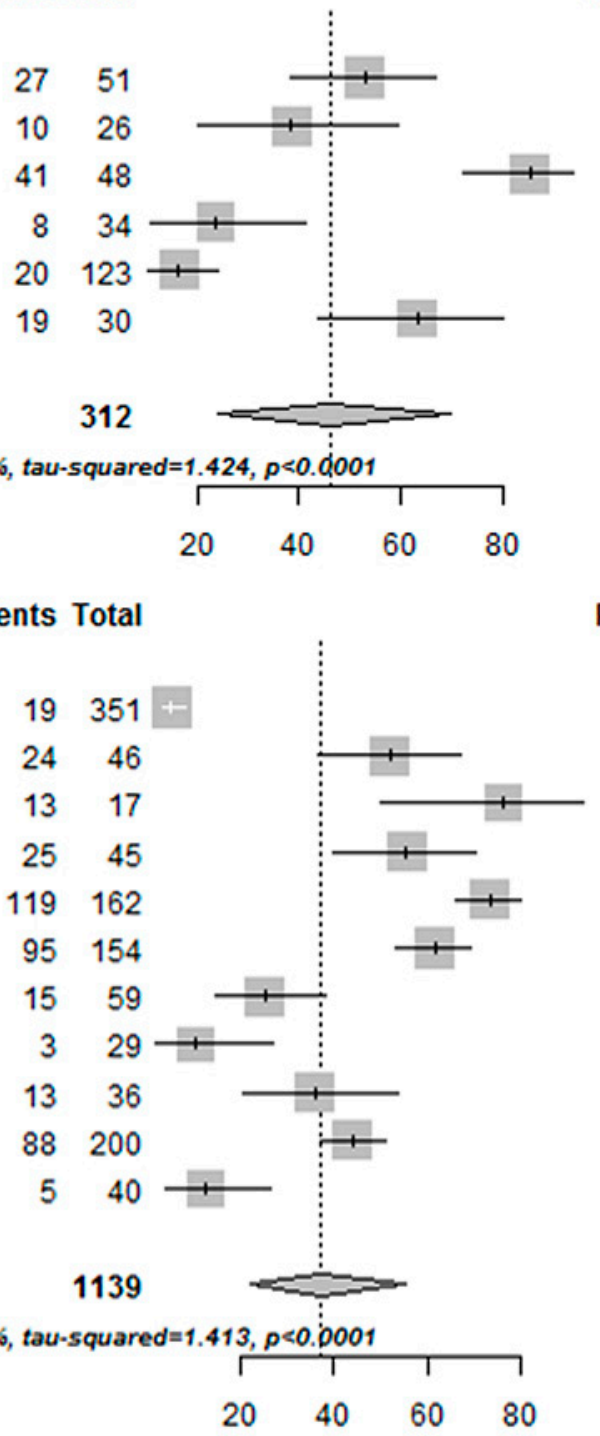

Prop (in \%) $\quad 95 \%-\mathrm{Cl}$ W(random)

$\begin{array}{ll}52.94[38.46 ; 67.07] & 17.2 \% \\ 38.46[20.23 ; 59.43] & 16.3 \% \\ 85.42[72.24 ; 93.93] & 16.3 \% \\ 23.53[10.75 ; 41.17] & 16.3 \% \\ 16.26[10.22 ; 23.99] & 17.4 \% \\ 63.33[43.86 ; 80.07] & 16.5 \% \\ & \\ \mathbf{4 6 . 0 9}[23.99 ; 69.85] & \mathbf{1 0 0 \%}\end{array}$

Prop (in \%) $\quad 95 \%-C l$ W(random)

$\begin{array}{rrr}5.41 & {[3.29 ; 8.32]} & 9.5 \% \\ 52.17[36.95 ; 67.11] & 9.3 \% \\ 76.47[50.10 ; 93.19] & 8.0 \% \\ 55.56[40.00 ; 70.36] & 9.3 \% \\ 73.46[65.96 ; 80.08] & 9.7 \% \\ 61.69[53.52 ; 69.40] & 9.7 \% \\ 25.42[14.98 ; 38.44] & 9.3 \% \\ 10.34[2.19 ; 27.35] & 7.8 \% \\ 36.11[20.82 ; 53.78] & 9.1 \% \\ 44.00[37.01 ; 51.17] & 9.7 \% \\ 12.50[4.19 ; 26.80] & 8.5 \% \\ & & \\ 37.42[22.33 ; 55.44] & 100 \%\end{array}$


Figure 3: Prevalence of xerostomia in patients with diabetes mellitus by continent.

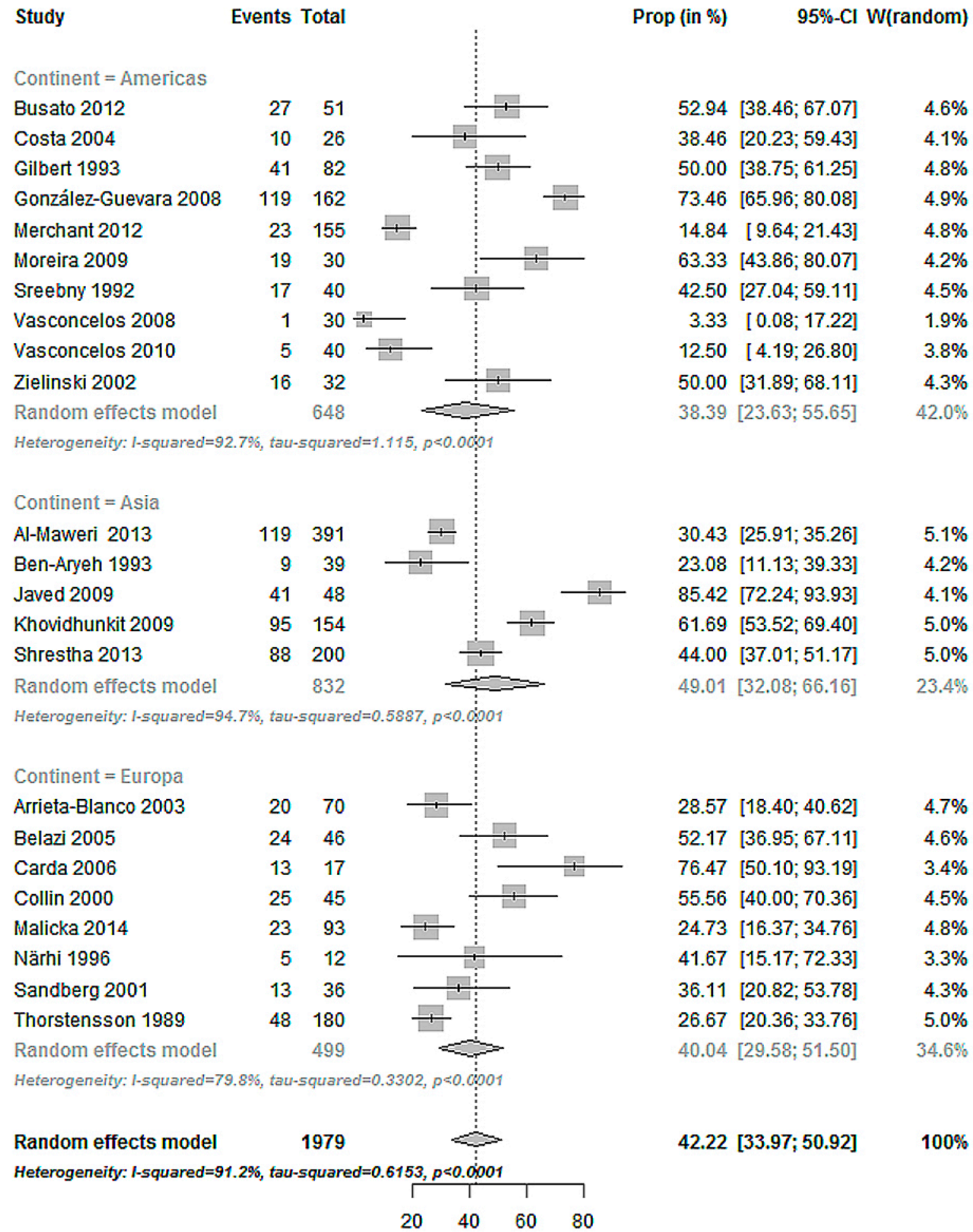


Figure 4: Analysis of case-control studies.

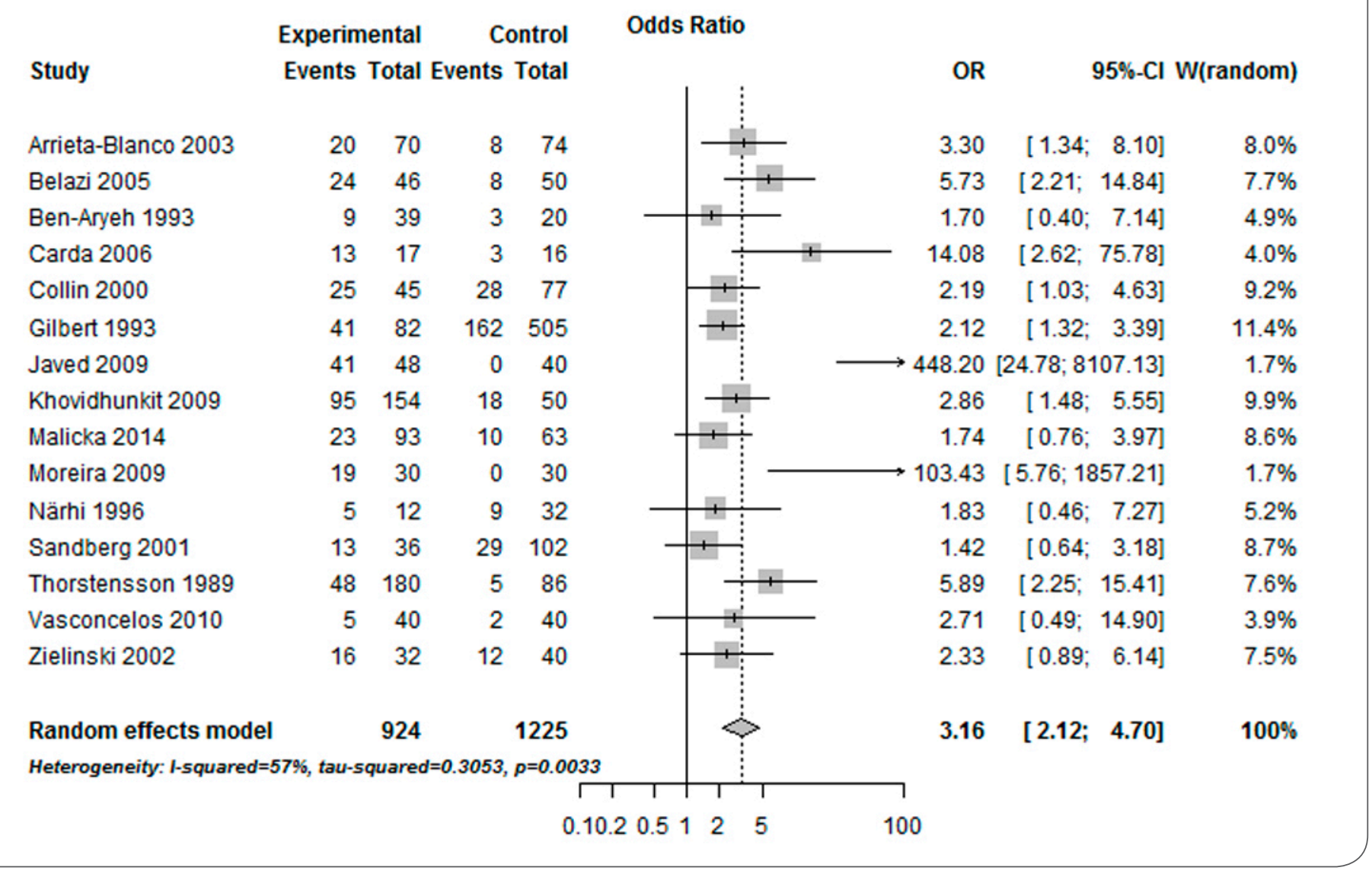

ristics were summarized according to odds ratios (Table 1 and Figure 4). The pooled data showed a statistically significant association between the occurrence of xerostomia and diabetes mellitus $(O R=3.15 ; 95 \% \mathrm{Cl}: 2.11$ to $4.70 ; \mathrm{p}<0.001)$, and the heterogeneity was moderate $\left(I^{2}=57 \% ; \tau^{2}=\right.$ 0.3053; $p=0.0033$ ).

The assessment of the publication bias of the 23 studies included in the meta-analysis and the 15 case-control studies is illustrated in the funnel plots shown in Figure 5. In the first chart, which shows the prevalence among the cases, the logit transformed prevalence of the analyzed studies is presented on the $x$-axis and the inverse of the standard error of each study is shown on the y-axis.

In the second chart, relating to the case-control studies, the inverse of the standard error is also shown on the $y$-axis and the OR of each study is placed on the x-axis. In both cases, the near symmetric distribution of the data suggests that there is no publication bias, which was confirmed by Egger's test in the cases $(p=0.4569)$ and the controls ( $p$ $=0.7714$ ).

\section{Discussion}

Xerostomia is a very frequent oral condition, capable of affecting oral functions and compromising the patient's general well-being [36]. Due to its complexity, its treatment requires an interdisciplinary approach that must be centered on improving quality of life, decreasing possible complications and promoting palliative care [37]. Its etiology has been associated with, among other factors, the presence of systemic diseases, including diabetes mellitus [36].

The findings of this systematic review and metaanalysis showed an overall prevalence of xerostomia of $42.22 \%$ (95\% Cl: 33.97\%-50.92\%) in people with diabetes and a statistically significant associa- 
Figure 5: Funnel plots estimating publication bias in cases (a) and case-controls (b).
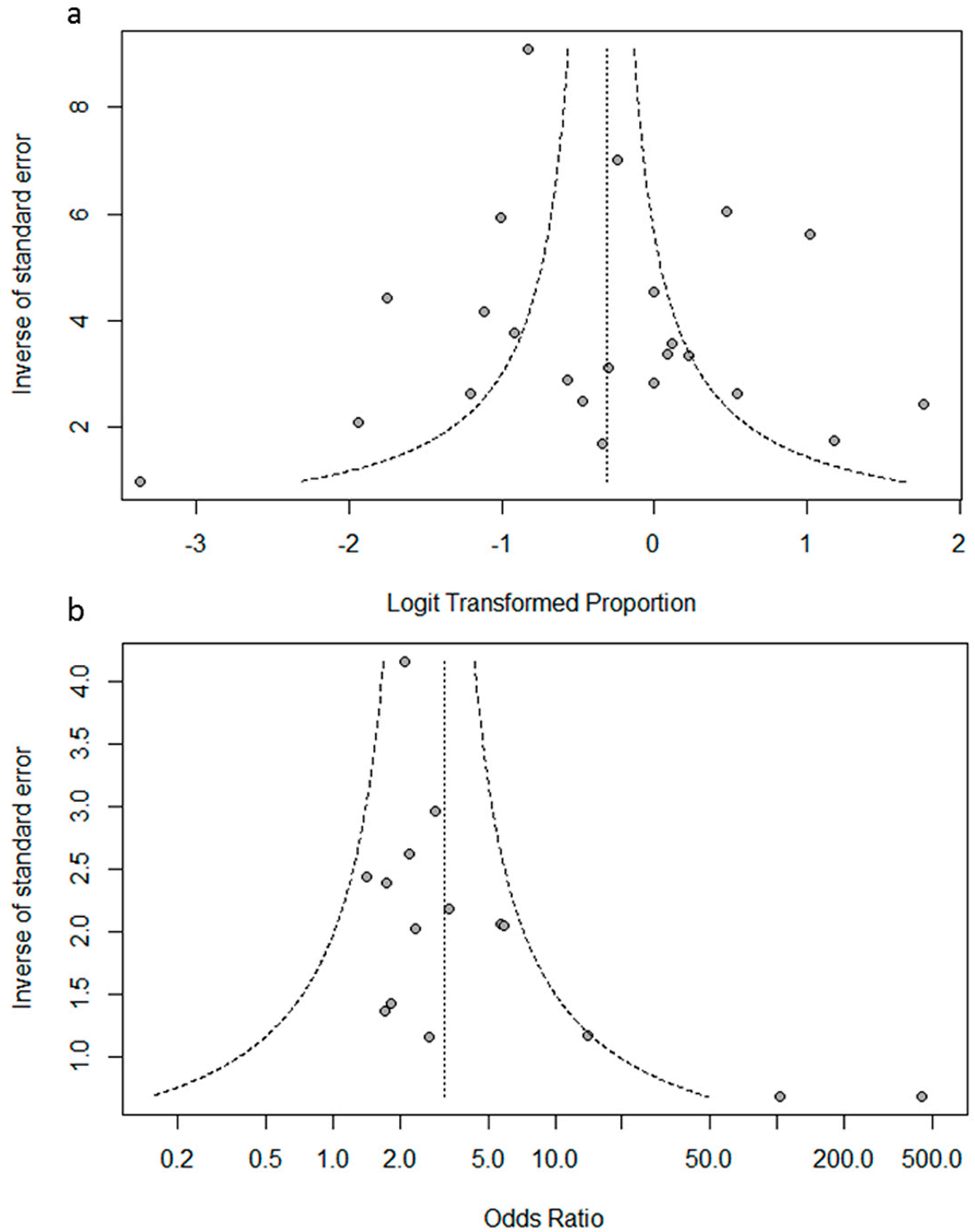
tion between xerostomia and diabetes mellitus (OR $=3.15 ; 95 \% \mathrm{Cl}: 2.11-4.70 ; \mathrm{p}<0.001)$. According to several authors, this association may be due to some characteristics of diabetes mellitus, such as dehydration by hyperglycemia, diabetic neuropathy, structural changes in the salivary glands and polyuria, which results in a subsequent reduction in the secretion of saliva [31, 38, 39, 40,41]. The increased diuresis in people with diabetes leads to a significant decrease in extracellular fluids that directly affects salivary production [18]. According to Moore [42], in periods of metabolic disorder, dehydration raises the osmotic gradient from the blood vessels in relation to the salivary glands, limiting saliva secretion and therefore exacerbating xerostomia symptoms [42]. Regarding structural aspects, a prospective observational study conducted by Rivera and Mendoza [43] found scientific evidence of cellular changes caused by diabetes mellitus and reduced salivary flow. According to the authors [43], this association had not been previously reported in the literature.

Apart from systemic diseases, recent studies noted the use of medication, especially polypharma$c y$, as one of the main risk factors for developing xerostomia [8, 44]. Among the drugs associated with decreased salivary flow, which can cause dry mouth, there are psycholeptics, psychoanaleptics, oral antidiabetics, respiratory agents, quinine, antihypertensive agents, urinary antispasmodics, glucosamine, non-steroidal anti-inflammatory drugs, opioids, ophthalmologic drugs and magnesium hydroxide [45]. Thus, it is possible that the prevalence of xerostomia found in in people with diabetes may be related, additionally, to the medications used to treat diabetes mellitus, its comorbidities and complications.

However, it is known that the feeling of dry mouth is not always associated with salivary gland hypofunction [7]. Corroborating this statement, a case-control study carried out in Greece showed normal levels of salivary production by more than a third of people with diabetes affected by xerosto- mia [15], suggesting that psychological factors may also influence the triggering of the disease [46].

Our data revealed high heterogeneity [10] in the analysis of prevalence of xerostomia in cases $\left(1^{2}=\right.$ 92.1\%; $\left.\tau^{2}=0.6153, p<0.001\right)$. To explore this heterogeneity, a subgroup analysis by continent and specific subtype of diabetes was performed.

In subjects affected by Type 1 diabetes mellitus, prevalence rates of xerostomia were between 16.26\% (95\% Cl: $10.22 \%-23.99 \%$ ) and $85.42 \%$ (95\% Cl: $72.24 \%-93.93 \%)$. In individuals affected by type 2 diabetes mellitus, the prevalence ranged from $3.33 \%$ (95\% Cl: 00.08\%-17.22\%) to $76.47 \%$ (95\% Cl: 50.10\%-93.19\%).

Seeking to explain the results above, in assessing the demographic profile of the studied sample, differences were observed regarding the age of individuals with Type 1 and Type 2 diabetes, who had been subdivided into children and/or adolescents and adults and/or elderly. Considering that xerostomia prevalence increases with age $[7,47]$, it is speculated that the age pattern found may have contributed to the increased prevalence among subjects with type 2 diabetes mellitus. However, this matter was not included in the meta-analysis due to insufficient data in these subgroups.

For studies included in the meta-analysis in which both diabetes subtypes were evaluated separately and compared, the difference between the prevalence of xerostomia in Type 1 and Type 2 diabetes was not statistically significant $[25,26]$.

As to the analysis by continent, the prevalence of xerostomia was similar in different parts of the world: $49.01 \%$ in Asia (95\% Cl: 32.08\%-66.16\%), $40.04 \%$ in Europe (95\% Cl: $29.58 \%-51.50 \%)$, and $38.39 \%$ in America (95\% Cl: 23.63\%-55.65\%). These results may represent a negative association between the presence of xerostomia and risk factors related to the specificities of each continent. This characteristic differs from diabetes mellitus, which features an uneven distribution around the world, with a higher prevalence in developing countries [2]. 
Because the subgroup analysis did not reveal much about heterogeneity, it is believed that the variation in the prevalence of xerostomia among the studies included in the meta-analysis may be due to the lack of standardization of diagnostic criteria [48].

Xerostomia is defined as dry mouth and, therefo$r e$, it is a subjective condition diagnosed by patient anamnesis [8]. In this regard, factors such as the level of discomfort for each individual and characteristics of the interview conducted by the researcher can influence the final outcome [8].

The sensitivity and specificity of using questionnaires as a diagnostic method for dry mouth was assessed by Sreenby and Valdini in 1988 through a study involving 529 individuals [49]. According to the authors, the positive response to the question "do you have the feeling of dry mouth frequently?" in an isolated manner demonstrated $93 \%$ sensitivity and $68 \%$ specificity, as well as a positive predictive value of $54 \%$ and a negative predictive value of $98 \%$. When associating three other questions related to different symptoms of xerostomia, specificity and positive predictive value increased to $91 \%$ and $75 \%$, respectively.

Although all 23 studies included in our metaanalysis diagnosed xerostomia using methods considered clinically appropriate, we observed differences regarding the number and content of the questions administered to the participants. For instance, some diagnoses were based solely on one question such as "Did you have the feeling of dry mouth every day for the last six months?" [17] or "Do you get the feeling of dry mouth frequently?" [34], whereas others used several questions: "Do you have the feeling of dry mouth frequently, " "Do you get the feeling of dry mouth during meals?" and "Do you have difficulty swallowing food without the help of a liquid substance?" [35].

According to Hopcraft and Tan [8], using only one question as a diagnostic method may be considered problematic because it often refers to specific situa- tions or periods in which the patient can experience xerostomia, basing the classification on an arbitrary cutoff point.

The prevalence of xerostomia by gender was not included in the meta-analysis as only three studies among those qualified for this step assessed the presence of xerostomia in men and women separately. In all cases, the authors reported that the prevalence was significantly higher among women $[22,30,31]$, data that corroborate other findings in the literature $[50,51]$.

In this regard, it is possible that the greater number of women in the study sample contributed to the increase in the overall prevalence of xerostomia between individuals affected by diabetes mellitus.

\section{Conclusion}

Through the data collected, we were able to infer that the prevalence of xerostomia in individuals affected by Type 1 and Type 2 diabetes mellitus was high and independent of geographic location. This association between two diseases that bring together different fields of healthcare reinforces the importance of interdisciplinary work in favor of the patient.

The heterogeneity found between all studies was high among cases and intermediate among casecontrols, so we recommend that the data presented here be interpreted with caution. In this regard, we emphasize the need to standardize the diagnosis of xerostomia to ensure the methodological quality of future studies.

\section{Conflict of Interest}

The authors have declared no Conflict of interest.

\section{References}

1. Alwan A, Maclean DR, Riley LM, d'Espaignet ET, Mathers CD, Stevens GA, et al. Monitoring and surveillance of chronic noncommunicable diseases: progress and capacity in high-burden countries. Lancet 2010; 376: 1861-8. 
2. Guariguata L, Whiting DR, Hambleton I, Beagley J, Linnenkamp U, Shaw JE. Global estimates of Diabetes prevalence for 2013 and projections for 2035. Diabetes Res Clin Pract 2014; 103 : 137-49.

3. Barros MBA, Francisco PMSB, Zanchetta LM, César CLG. Cienc saude coletiva 2011; 16: 3755-68.

4. Ministério da Saúde (Brasil). Secretaria de Atenção à Saúde. Departamento de Atenção Básica. Diabetes Mellitus. Brasília: Ministério da Saúde, 2006.

5. International Diabetes Federation. About Diabetes; 2014; http://www.idf.org/about-Diabetes available at: http://www.idf. org/about-Diabetes [last accessed 25 October 2014].

6. Ministério da Saúde (Brasil). Secretaria de Atenção à Saúde. Departamento de Atenção Básica. Saúde Bucal. Brasília: Ministério da Saúde, 2008

7. Edgar M, Dawes C, O'mullane, D. Saliva e Saúde Bucal. 3. ed. Santos: Santos; 2010.

8. Hopcraft MS, Tan C. Xerostomia: an update for clinicians. Aust Dent J 2010; 55: 238-44.

9. Handelsman Y, Mechanick Jl, Blonde L, Grunberger G, Bloomgarden ZT, Bray GA, et al. Task Force for Developing Diabetes Comprehensive Care Plan. American Association of Clinical Endocrinologists Medical Guidelines for Clinical Practice for developing a Diabetes Mellitus comprehensive care plan. Endocr Pract 2011; 17: 1-53

10. Higgins JP, Thompson SG, Deeks JJ, Altman DG. Measuring inconsistency in meta-analyses. BMJ 2003; 327: 557-60.

11. Higgins JPT, Green S (editors). Cochrane Handbook for Systematic Reviews of Interventions Version 5.1.0. The Cochrane Collaboration, 2011.

12. Zhou A, Obuchowski N, McClish D. Statistical methods in diagnostic medicine. New York: Wiley \& Sons, 2002.

13. Al-Maweri SA, Ismail NM, Ismail AR, Al-Ghashm A. Prevalence of oral mucosal lesions in patients with type 2 Diabetes attending hospital universiti sains malaysia. Malays J Med Sci 2013; 20 : 39-46

14. Arrieta-Blanco JJ, Bartolomé-Villar B, Jiménez-Martinez $E$ Saavedra-Vallejo P, Arrieta-Blanco FJ. Problemas bucodentales en pacientes con Diabetes Mellitus (I): Índice de placa y caries dental. Med Oral 2003; 8: 97-109.

15. Belazi M, Velegraki A, Fleva A, Gidarakou I, Papanaum L, Baka $D$, et al. Candidal overgrowth in diabetic patients: potential predisposing factors. Mycoses 2005; 48: 192-6.

16. Ben-Aryeh $H$, Serouya $R$, Kanter $Y$, Szargel $R$, Laufer D. Oral health and salivary composition in diabetic patients. J Diabetes Complications 1993; 7: 57-62.

17. Busato IM, Ignácio SA, Brancher JA, Moysés ST, AzevedoAlanis LR. Impact of clinical status and salivary conditions on xerostomia and oral health-related quality of life of adolescents with type 1 Diabetes Mellitus. Community Dent Oral Epidemiol 2012; 40: 62-9
18. Carda C, Mosquera-Lloreda N, Salom L, Gomez de Ferraris ME, Peydró A. Structural and functional salivary disorders in type 2 diabetic patients. Med Oral Patol Oral Cir Bucal 2006; 11: E30914.

19. Collin HL, Niskanen L, Uusitupa M, Töyry J, Collin P, Koivisto AM, et al.. Oral symptoms and signs in elderly patients with type 2 Diabetes Mellitus. A focus on diabetic neuropathy. Oral Surg Oral Med Oral Pathol Oral Radiol Endod 2000; 90: 299-305.

20. Costa CC, Resende GB, Souza JM, Tavares SS, Almeida IC, Filho LC. Study of the oral manifestations in diabetic children and their correlation variables. Arq Bras Endocrinol Metabol 2004; 48: 374-8.

21. Gilbert GH, Heft MW, Duncan RP. Mouth dryness as reported by older Floridians. Community Dent Oral Epidemiol 1993; 21: 390-7.

22. González-Guevara MB, Linares-Vieyra C, Rodríguez-de Mendoza LE. Prevalence of buccal lesions on type 2 Diabetes Mellitus. Rev Med Inst Mex Seguro Soc 2008; 46: 237-45.

23. Javed F, Sundin U, Altamash M, Klinge B, Engström PE. Selfperceived oral health and salivary proteins in children with type 1 Diabetes. J Oral Rehabil 2009; 36: 39-44.

24. Khovidhunkit SO, Suwantuntula T, Thaweboon S, Mitrirattanakul S, Chomkhakhai U, Khovidhunkit W. Xerostomia, hyposalivation, and oral microbiota in type 2 diabetic patients: a preliminary study. J Med Assoc Thai 2009; 92: 1220-8.

25. Malicka B, Kaczmarek U, Skośkiewicz-Malinowska K. Prevalence of xerostomia and the salivary flow rate in diabetic patients. Adv Clin Exp Med 2014; 23: 225-33.

26. Merchant AT, Oranbandid S, Jethwani M, Choi YH, Morrato EH, Pitiphat $\mathrm{W}$, et al.. Oral care practices and $\mathrm{A} 1 \mathrm{c}$ among youth with type 1 and type 2 Diabetes. J Periodontol 2012; 83: 856-63.

27. Moreira AR, Passos IA, Sampaio FC, Soares MS, Oliveira RJ. Flow rate, $\mathrm{pH}$ and calcium concentration of saliva of children and adolescents with type 1 Diabetes Mellitus. Braz J Med Biol Res 2009; 42: 707-11

28. Närhi TO, Meurman JH, Odont D, Ainamo A, Tilvis R. Oral health in the elderly with non-insulin-dependent Diabetes Mellitus. Spec Care Dentist 1996; 16: 116-22.

29. Sandberg GE, Sundberg HE, Wikblad KF. A controlled study of oral self-care and self-perceived oral health in type 2 diabetic patients. Acta Odontol Scand 2001; 59: 28-33.

30. Shrestha AD, Kosalram K, Gopichandran V. Gender difference in care of type 2 Diabetes. JNMA J Nepal Med Assoc 2013; 52: 245-50

31. Sreebny LM, Yu A, Green A, Valdini A. Xerostomia in Diabetes Mellitus. Diabetes Care 1992; 15: 900-4.

32. Thorstensson H, Falk H, Hugoson A, Kuylenstierna J. Dental care habits and knowledge of oral health in insulin-dependent diabetics. Scand J Dent Res 1989; 97: 207-15. 
33. Vasconcelos $B C$, Novaes $M$, Sandrini FA, Maranhão Filho AW, Coimbra LS. Prevalence of oral mucosa lesions in diabetic patients: a preliminary study. Braz J Otorhinolaryngol 2008; 74: 423-8.

34. Vasconcelos AC, Soares MS, Almeida PC, Soares TC. Comparative study of the concentration of salivary and blood glucose in type 2 diabetic patients. J Oral Sci 2010; 52: 293-8.

35. Zielinski MB, Fedele D, Forman LJ, Pomerantz SC. Oral health in the elderly with non-insulin-dependent Diabetes Mellitus. Spec Care Dentist 2002; 22: 94-8.

36. Mortazavi H, Baharvand M, Movahhedian A, Mohammadi M, Khodadoustan A. Xerostomia due to systemic disease: a review of 20 conditions and mechanisms. Ann Med Health Sci Res 2014; 4: 503-10.

37. Plemons JM, Al-hashimi I, Marek CL. Managing xerostomia and salivary gland hypofunction: executive summary of a report from the American Dental Association Council on Scientific Affairs. J Am Dent Assoc 2014; 145: 867-73.

38. Carda C, Carranza M, Arriaga A, Díaz A, Peydró A, Gomez de Ferraris ME. Structural differences between alcoholic and diabetic parotid sialosis. Med Oral Patol Oral Cir Bucal 2005; 10 : 309-14.

39. Vernillo AT. Dental considerations for the treatment of patients with Diabetes Mellitus. J Am Dent Assoc 2003; 134: 24S-33S.

40. Närhi TO. Prevalence of subjective feelings of dry mouth in the elderly. J Dent Res 1994; 73: 20-5.

41. Dodds MW, Yeh CK, Johnson DA. Salivary alterations in type 2 (insulin-dependent) Diabetes Mellitus and hypertension. Community Dent Oral Epidemiol 2000; 28: 373-81.

42. Moore PA, Guggenheimer J, Etzel KR, Weyant RJ, Orchard T. Type 1 Diabetes Mellitus, xerostomia, and salivary flow rates. Oral Surg Oral Med Oral Pathol Oral Radiol Endod 2001; 92: 281-91.

43. Rivera C, Núñez-de-Mendoza C. Exfoliative cytology of oral epithelial cells from patients with type 2 Diabetes: cytomorphometric analysis. Int J Clin Exp Med 2013; 6: 667-76.

44. Villa A, Polimeni A, Strohmenger $L$, Cicciù D, Gherlone E, Abati S. Dental patients' self-reports of xerostomia and associated risk factors. J Am Dent Assoc 2011; 142: 811-6.

45. Smidt D, Torpet LA, Nauntofte B, Heegaard KM, Pedersen AM. Associations between labial and whole salivary flow rates, systemic diseases and medications in a sample of older people. Community Dent Oral Epidemiol 2010; 38: 422-35.

46. Bergdahl M, Bergdahl J. Low unstimulated salivary flow and subjective oral dryness: association with medication, anxiety, depression, and stress. J Dent Res 2000; 79: 1652-8.

47. Johansson AK, Johansson A, Unell L, Ekbäck G, Ordell S, Carlsson GE. Self-reported dry mouth in Swedish population samples aged 50, 65 and 75 years. Gerodontology 2012; 29: e107-15
48. Löfgren CD, Wickström C, Sonesson M, Lagunas PT, Christersson C. A systematic review of methods to diagnose oral dryness and salivary gland function. BMC Oral Health 2012; 12: 29.

49. Sreebny LM, Valdini A. Xerostomia. Part I: Relationship to other oral symptoms and salivary gland hypofunction. Oral Surg Oral Med Oral Pathol 1988; 66: 451-8.

50. Bakke M, Larsen SL, Lautrup C, Karlsborg M. Orofacial function and oral health in patients with Parkinson's disease. Eur J Oral Sci 2011; 119: 27-32.

51. Bergdahl M. Salivary flow and oral complaints in adult dental patients. Community Dent Oral Epidemiol 2000; 28: 59-66.

\section{Comment on this article:}

\section{$4[8$ in $8+\mathcal{S} P$}

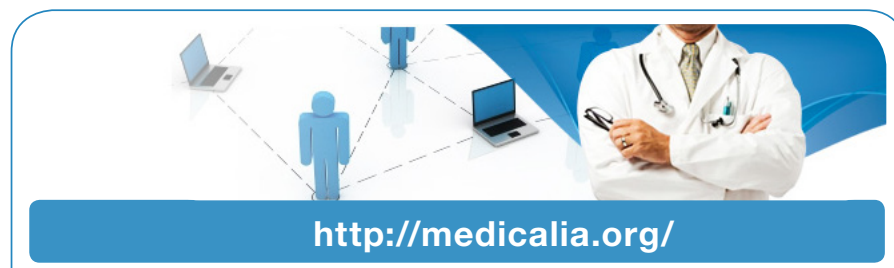

Where Doctors exchange clinical experiences, review their cases and share clinical knowledge. You can also access lots of medical publications for free. Join Now!

\section{Publish with iMedPub}

\section{http://www.imed.pub}

International Archives of Medicine is an open access journal publishing articles encompassing all aspects of medical science and clinical practice. IAM is considered a megajournal with independent sections on all areas of medicine. IAM is a really international journal with authors and board members from all around the world. The journal is widely indexed and classified Q1 in category Medicine. 